\title{
PENGARUH PRICE FAIRNESS TERHADAP REPURCHASE INTENTION HIGH END MAKE UP DAN SKIN CARE PADA GENERASI MILENIAL DI JAKARTA
}

\author{
Oktafalia Marisa \\ Universitas Bunda Mulia, Jakarta \\ omuzammil@bundamulia.ac.id \\ Janny Rowena \\ Universitas Bunda Mulia, Jakarta, \\ jrowena@bundamulia.ac.id
}

\begin{abstract}
Millennial generation economy behavior is very different from previous generations. Both generation $X$ or even further generations. Generations before millennial save money for the future. While the millennial generation save money for certain purposes. Savings are more short term. So it's easier to spend money on savings and tend not to be ready for future savings. Millennials often spend money beyond their capabilities, the more limited the goods, the more 'stylish' they feel if they can upload it to social media. This study wants to find out whether the purchase decision will then be followed by a repurchase decision on products that are classified as not cheap to satisfy the lifestyle of the generation. The analytical method that researchers use is multiple regression. The purpose of this study is to see whether there is an influence of price fairness on the repurchase intention of high end make up and skin care millennial generation?The results revealed that price fairness had a significant effect on repurchase intention.
\end{abstract}

Keywords: price fairness, repurchase intention

\section{PENDAHULUAN}

Perilaku "ekonomi” generasi milenial tentunya sangat berbeda dari generasigenerasi sebelumnya. Baik generasi $\mathrm{X}$ atau bahkan generasi yang lebih jauh lagi. Kebiasaan menabung bisa menjadi contoh paling mudah. Generasi sebelum milenial menabung untuk jaga-jaga di masa depan. Dalam arti sebagai cadangan keperluan yang tidak pasti atau tidak terduga. Sementara generasi milenial menabung untuk keperluan yang sudah pasti. Menabungnya lebih bersifat jangka pendek. "Easy come easy go. Jadi lebih mudah membelanjakan uang tabungan dan cenderung tidak siap untuk tabungan masa depan. Tetapi positifnya mereka tahu apa yang mereka mau, dan selalu berusaha keras mewujudkannya seringkali generasi milenial menghabiskan dana di luar kemampuan anggarannya, semakin terbatas barangnya, maka mereka akan merasa semakin 'bergaya' jika dapat 
mengunggahnya ke media sosial. Perilaku melibatkan media sosial dalam hampir seluruh sisi kehidupannya ini merupakan salah satu ciri khas generasi milenial yang dekat sekali dengan penggunaan teknologi, perkembangan perilaku konsumen yang merupakan generasi milenial di Indonesia sangat pesat dilihat dari akses teknologi digital. Pengambilan keputusan pembelian konsumen melalui penggalian informasi digital sebagai sumber referensi terpercaya bahkan dapat menjadi sumber inspirasi. Youtuber maupun Selebgram merupakan salah satu contoh profesi baru yang muncul kepermukaan yang menjadikan konten digital sebagai produk untuk dipasarkan kemudian dikonsumsi oleh masyarakat sebagai end-user dalam membantu masyarakat untuk mempermudah proses pembelian. Pada penelitian sebelumnya mengenai pengaruh perilaku pembelian terhadap keputusan pembelian high end make up and skin care pada generasi milenial jakarta, diperoleh hasil bahwa secara simultan terdapat pengaruh yang signifikan dari perilaku pembelian terhadap keputusan pembelian oleh generasi milenial, hal ini membuat kami selaku peneliti ingin mengetahui apakah keputusan pembelian tersebut kemudian akan diikuti dengan keputusan pembelian kembali terhadap produk yang tergolong tidak murah untuk memuaskan gaya hidup generasi tersebut.

Batasan Masalah

1. Penelitian dilakukan pada pengunjung Sephora store Jakarta yang masih tergolong generasi milenial

2. Waktu pengumpulan data adalah pada rentang periode Oktober hingga Desember 2019

3. Responden hanyalah yang sudah melakukan pembelian kembali dari produk high end make up dan skin care

\section{Rumusan Masalah}

Apakah terdapat pengaruh dari price fairness terhadap repurchase intention pembelian produk high end make up dan skin care generasi milenial? 


\section{TINJAUAN LITERATUR}

Pemasaran

Pemasaran adalah hal yang penting untuk dilakukan dengan benar, karena pemasaran sendiri berkaitan secara langsung dengan konsumen menurut The American Marketing Association dalam Kotler dan Keller (2016) mendefinisikan pemasaran sebagai berikut, "Marketing is the activity, set of institutions, and processes for creating, communicating, delivering, and exchanging offerings that have value for customers, clients, partners, and society at large". Pemasaran adalah aktivitas, mengatur institusi, dan proses untuk menciptakan, berkomunikasi, memberikan, dan bertukar penawaran yang memiliki nilai bagi pelanggan, klien, mitra, dan masyarakat pada umumnya.

\section{Konsumen}

Menurut Sangadji dan Sopiah (2013:30), konsumen diklasifikasikan menjadi 2 macam yaitu konsumen individu dan konsumen organisasi. Konsumen individu adalah orang-orang atau individu-individu yang membeli produk (barang, jasa, atau ide) untuk dikonsumsi sendiri, bersama anggota keluarga, atau berama teman2.
Sedangkan konsumen organisasi diartikan sebagai lembaga atau instansi yang membeli produk (barang, jasa, atau ide) untuk diperjualbelikan atau untuk kepentingan instansi atau lembaga tersebut.

\section{Harga}

Menurut Basu Swastha (2009), tahaptahap dalam penetapan harga antara lain:

Mengestimasikan permintaan untuk barang tersebut.

Pada tahap ini penjual membuat estimasi permintaan barangnya secara total. Pengestimasian permintaan barang dapat dilakukan dengan cara:

1) Menentukan harga yang diharapkan, yaitu harga yang diharapkan dapat diterima oleh konsumen.

2) Mengestimasikan volume penjualan pada berbagai tingkat harga.

Mengetahui lebih dulu reaksi dalam persaingan.

Kondisi persaingan sangat mempengaruhi kebijaksanaan penentuan harga perusahaan atau penjual. Oleh karena itu, penjual perlu mengetahui reaksi persaingan yang terjadi di pasar serta sumber-sumber 
penyebabnya. Adapun sumber-sumber persaingan yang ada dapat berasal dari:

1. Barang sejenis yang dihasilkan dari perusahaan lain

2. Barang pengganti atau substitusi.

3. Barang-barang lain yang dibuat oleh perusahaan lain yang samasama menginginkan uang konsumen.

\section{Price Fairness}

Price fairness (kewajaran harga) merupakan suatu penilaian untuk suatu hasil dan proses yang dapat diterima oleh konsumen. Kewajaran harga kemungkinan besar didasarkan pada perbandingan transaksi yang melibatkan berbagai pihak ketika terjadi perbedaan harga, maka tingkat kesamaan antara transaksi merupakan unsur penting dari penilaian kewajaran harga (Curatman dan Hermansyah, 2015). Price fairness merupakan variabel keputusan yang berpotensi dapat mempengaruhi loyalitas konsumen. Dalam banyak kasus, pada saat ini kepuasan pelanggan mengalihkan fokus pada harga pelayanan dan kualitas pelayanan (Hasan, 2008). Harga merupakan satusatunya elemen yang paling menentukan bagi perusahaan untuk mendapatkan pendapatan (Budianto, 2015). Menurut Consuegra, et. al. (2007) mendefinisikan bahwa kewajaran sebagai suatu penilaian untuk suatu hasil dan proses agar mencapai hasil yang masuk akal dan dapat diterima. Aspek kognitif yang menunjukkan bahwa 16 kewajaran harga melibatkan perbandingan prosedur harga yang terkait dengan standar, referensi atau norma. Kewajaran harga dapat diukur dengan beberapa atribut sebagai berikut:

1. Referensi tingkat harga yang dimana konsumen merasa wajar jika suatu produk atau jasa yang sama jenisnya dari perusahaan yang berbeda tetapi dengan harga yang berbeda

2. Kebijakan harga yang ditentukan oleh perusahaan adalah harga wajar dan dapat diterima oleh pelanggan

3. Harga yang ditetapkan merupakan sebuah etika, yang artinya dimana kondumen selalu diberitahu mengenai perubahan harga yang dilakukan oleh perusahaan.

Price fairness is the judgement of and comparison between the buyer"s 
perceived reference price and the seller"s actual prices. Price fairness adalah pandangan dan perbandingan antara harga referensi yang dirasakan pembeli dan harga aktual penjual El Haddad et al (2015). Dalam hal ini price fairness dapat diartikan sebagai pandangan konsumen terhadap referensi harga atau harga yang sudah dirasakan, dengan harga yang sebenarnya, yaitu harga yang telah dirasakan konsumen

\section{Konsep Price Fairness}

Pentingnya menetapkan harga yang pantas untuk meraih suatu keuntungan dalam suatu perusahaan, karena penetapan harga tersebut akan berdampak terhadap peningkatan pendapatan dalam perusahaan, perusahaan harus lebih teliti dan cerdas untuk menetapkan suatu harga yang pantas. The business units key objective for the period may be to increase the rate of return on investment. Managers can increase profit by increasing revenue and reducing expenses. They can grow revenue, in turn, by increasing market share and prices (Kotler \& Keller, 2016, hlm. 47). Tujuan utama unit bisnis untuk periode mungkin untuk meningkatkan tingkat pengembalian investasi. Manajer dapat meningkatkan keuntungan dengan meningkatkan pendapatan dan mengurangi biaya. Perusahaan dapat meningkatkan pendapatan, pada gilirannya, dengan meningkatkan pangsa

Faktor yang mempengaruhi Price Fairness

Pada dasarnya penetapan harga yang wajar atau price fairness dipengaruhi oleh berbagai aspek baik dari pihak perusahaan itu sediri maupun dari market share perusahaan dimana perusahaan akan menekankan harga yang dirasa wajar atau harga rendah agar tamu mersakan manfaat dari produk dan jasa yang diterima sangat bermanfaat seperti teori yang dikemukaan Kotler \& Keller (2016) sebagai berikut. Some companies want to maximize their market share. They believe a highersales volume will lead to lower unit costs and higher long-run profit, so they set the lowest price, assuming the market is price sensitive. The company would build a large plant, set its price as low as possible, win a large market share, experience falling costs, and cut its price further as costs fell 


\section{Repurchase Intention}

Menurut teori Suryani dalam jurnal Rizal (2013), melakukan pembelian secara teratur atau berulang adalah pelanggan yang telah melakukan pembelian suatu produk sebanyak dua kali atau lebih. Sedangkan menurut teori Schiffman-Kanuk dalam jurnal Rizal (2013), ada dua tipe pembelian yaitu pembelian untuk percobaan dan

\section{METODOLOGI PENELITIAN}

Variabel Penelitian

Variabel independen yang digunakan dalam penelitian ini adalah variabel price fairness. Variabel dependen adalah variabel yang tidak dapat berdiri sendiri dan tergantung dari variabel lainnya.Variabel dependen yang digunakan dalam penelitian ini adalah repurchase intention $(\mathrm{y})$.

Populasi Penelitian

Populasi dalam penelitian ini adalah konsumen yang melakukan pembelian pada produk high end make up and skin care, sedangkan sampel dalam penelitian ini adalah responden milenial yang melakukan pembelian kembali produk high end make up dan skin care di Sephora store. pembelian ulang. Pembelian percobaan merupakan tahap penyelidikan dari perilaku pembelian dimana konsumen berusaha mengevaluasi produk dengan mencoba. Jika suatu produk dibeli dengan percobaan ternyata memuaskan atau atau lebih memuaskan dari produk sejenis yang sebelumnya digunakan, maka konsumen berkeinginan untuk membeli ulang (repurchase behavior).

Jenis dan Sumber Data

Data yang digunakan adalah hasil jawaban responden atas pertanyaan yang diajukan dalam wawancara baik secara lisan dan melalui kuesioner.

Pengembangan Instrumen

Metode Pengumpulan Data

1. Kuesioner

Kuesioner adalah metode pengumpulan data dengan cara memberikan atau menyebarkan daftar pertanyaan/pernyataan kepada responden dengan harapan responden memberikan respon atas pertanyaan tersebut.

2. Wawancara

Wawancara yang digunakan 
dalam penelitian ini dilakukan para konsumen

yang melakukan pembelian kembali produk high end make up and skin care di Sephora store yang termasuk dalam generasi milenial

3. Observasi

Observasi merupakan teknik pengumpulan data dengan cara melakukan pengamatan dan pencatatan secara sistemik terhadap fenomena yang diselidiki secara langsung ke obyek penelitian. Dalam hal ini observasi dilakukan dengan pengamatan lengsung terhadap obyek penelitian.
Teknik Analisis Data

Analisis Kualitatif

Analisis kualitatif untuk membahas dan menerangkan hasil penelitian tentang keputusan pembelian generasi milenial yang melakukan pembelian produk high end make up and skin care di Sephora store

\section{Analisis Regresi Linier Berganda}

Analisis regresi linier berganda digunakan untuk mengetahui pengaruh variabel bebas terhadap variabel terikat, di mana variabel bebasnya meliputi prosedur variabel brand image $\left(\mathrm{x}_{1}\right)$, harga $\left(\mathrm{x}_{2}\right)$, dan kualitas produk $\left(\mathrm{x}_{3}\right)$. sedangkan variabel independen adalah keputusan pembelian kembali (y).

\section{HASIL PENELITIAN DAN PEMBAHASAN}

Penelitian ini dilakukan kepada mereka yang telah melakukan pelanggan Sephora yang merupakan pembelian berulang dan masih dalam store retail yang hanya menjual high kriteria generasi milenial. Dalam end make up and skin care. Konsumen penelitian ini terpilih 25 sampel yang yang terpilih dalam penelitian ini adalah dianggap memenuhi kriteria sampel. 
Tabel 1. Hasil uji pengaruh dengan menggunakan uji t (secara parsial)

\begin{tabular}{cccccc} 
Model & \multicolumn{2}{c}{$\begin{array}{c}\text { Unstandardized } \\
\text { Coefficients }\end{array}$} & $\begin{array}{c}\text { Standardized } \\
\text { Coefficients }\end{array}$ & t & Sig. \\
& B & $\begin{array}{c}\text { Std. } \\
\text { Error }\end{array}$ & Beta & & \\
\hline Constant $)$ & 179.103 & 18.249 & & 9.814 & .000 \\
$\begin{array}{c}\text { Price } \\
\text { Fairnerss }\end{array}$ & .044 & .008 & -.430 & 5.334 & .001
\end{tabular}

a. Dependent Variable: Repurchase Intention

Sumber: Hasil pengolahan SPSS, 2019

Pengaruh Price Fairness terhadap Repurchase Intention

Berdasarkan hasil analisis data terbukti bahwa Price Fairness memiliki pengaruh signifikan terhadap Repurchase Intention. Nilai signifikansi $0,001<\alpha=0,05$ maka terdapat pengaruh yang signifikan Price Fairness terhadap Repurchase Intention dengan tingkat keyakinan 95\%. Hal tersebut menunjukkan bahwa kewajaran harga mempunyai pengaruh yang positif dan signifikan terhadap minat beli ulang. Hasil penelitian ini juga senada dengan pendapat yang dikemukakan oleh Wang \& Chen (2016) yang membahas tentang persepsi harga yang sesuai akan memberikan pengaruh langsung terhadap perceived value, perceived risk dan minat beli ulang.

\section{Tabel 2. Hasil uji R Square}

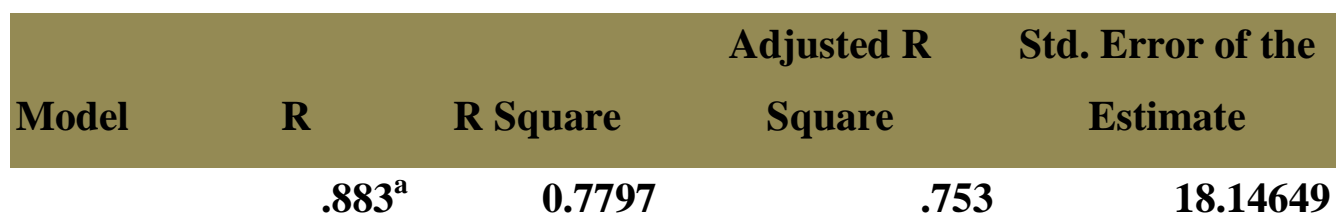

a. Predictors: (Constant)

b. Dependent Variable: Repurchase Intention 
Nilai $\mathrm{R}^{2} \quad$ (koefisien determinasi) digunakan untuk mengetahui besarnya kontribusi (pengaruh) yang diberikan oleh variabel independen (X) terhadap variabel dependen (Y). koefisien determinasi ganda atau koefisien

\section{SIMPULAN DAN SARAN}

Dari penelitian sebelumnya, terungkap bahwa generasi milenial dengan segala keunikannya sangat tertarik dalam pembelian produk high end make up dan skin care, hal ini diperkirakan karena kebutuhan mereka untuk memenuhi keinginan atau target jangka pendek, kebutuhan lainnya adalah untuk eksis dengan dengan di lingkungan sosial mereka dengan pemanfaat digital teknologi dan sosial media yang mereka kuasai, di tambah lagi faktor psikologis yang menyiratkan kaum milenial akan senantiasa memenuhi gaya hidup hedonisme. Namun, dalam penelitian ini juga memberikan hasil bahwa fair priceness juga memberikan pengaruh signifikan atas variabel repurchase intention. Dengan demikian generasi milenial memperhatikan kewajaran harga untuk keputusan pembelian kembali, apabila harga berbanding lurus dengan kualitas maka mereka akan melakukan pembelian kembali. Apabila penentu adalah sebesar $77.97 \%$. Artinya, variansi variabel repurchase intention sebesar $77.97 \%$ dapat dijelaskan oleh variabel price fairness, sedangkan sisanya sebesar $22.03 \%$ dapat dijelaskan oleh variabel lainnya.

tidak maka mereka tidak akan sungkan untuk membeli produk yang berbeda. Hal ini juga di mungkinkan dengan kemudahan akses informasi mengenai produk pesaing yang sejenis. Kemudahan akses ini tentunya lagi-lagi didukung oleh pemanfaatan teknologi yang mereka kuasai, belum lagi trend para influencer yang berasal dari selebgram ataupun vlogger yang kencang sekali mendapatkan endorse dari berbagai produsen untuk mempromosikan produk-produk yang beragam. Dari hasil penelitian sebelumnya, terlihat bahwa adanya budaya untuk percaya bahwa produk high end make up dan skin care yang tidak murah akan memberikan efek yang baik. Kualitas ditentukan harga yang dibandrol pada suatu produk. Hal ini kemudian memicu fenomena menarik pada produk make up dan skin care lokal yang memilih membandrol produk mereka dengan harga yang relatif tinggi untuk menunjukkan bahwa 
produk mereka memiliki kualitas baik, tidak kalah dengan produk dari luar negeri dan tepat untuk memenuhi gaya hidup hedonis generasi milenial saat ini. Namun kita tentunya tidak boleh melupakan fakta bahwa generasi milenial adalah generasi yang sangat mudah berpaling dari satu trend ke trend selanjutnya, dengan demikian mereka juga lebih menuntut terhadapat harga yang wajar, dalam hal ini adalah berbanding lurus dengan kualitas, maka

\section{DAFTAR PUSTAKA}

Ahmad, Rizal. (2013). Pengaruh

Kualitas Pelayanan, Kualitas

Produk, dan Harga Terhadap Kepuasan Konsumen Untuk Mendorong Pembelian Ulang (Studi Kasus pada PT.Restomart Cipta Usaha Cabang Semarang). Jurnal Dinamika Manajemen, Vol 2, No 2, Hal.65-80.

Budianto, Apri. (2015). Manajemen

Pemasaran. Ombak : Yogyakarta.

Consuegra, et al. (2007). An Integrated Model Of Price, Satisfaction and Loyalty: An Empirical Analysis In The Service Sector. Emerald Group Publishing Limited. Journal of Product and Brand Management, volume 16 , number 7, 2007, pp. 459-468.

Curatman, A., dan Hermansyah. (2015). Membangun Kepuasan Konsumen Melalui Kewajaran Harga dan Merk Pribadi (Survey Pada Konsumen Giant Kota kami menyarankan pada produsen untuk selalu mempertahankan kualitas dan keunikannya serta terus menciptakan hal kekinian yang membuat generasi ini terus tertarik menggunakan produk pilihannya di tengah banyaknya pilihan lainnya. Faktor ini menarik untuk dikembangkan sehingga pada penelitian selanjutnya kami menyarankan untuk meneliti secara lebih mendalam.

Cirebon). Jurnal Logika, XIV (2), $42-49$

El Haddad, Rania. (2015) "Price

Fairness Perceptions and Hotel Customer's Behavioral Intentions". Journal of Vacation Marketing.

Hasan, Tanveer. (2008). Influence of Brand Name on Consumer Decision in Car Choice. Thesis. Umea School of Business and Economics.

Hermann et al. (2007). The Influence of Price Fairness on Customer Satisfaction: An Empirical Test in The Context of Automobile Purchases". Journal of Product \& Brand Management. Vol.16, No.1, pp 49-58.

Kotler, Philip and Kevin Lane Keller. (2016). Marketing Management. 15th Edition, Pearson Education,Inc. 
Kotler, Philip \& Gary Amstrong (2011). Principle of Marketing, 10th Edition/International Edition. of Marketing, Vol. 68, October, New Jersey; Prentice Hall

Monroe, K. B., \& Krishnan, R. (1985).

The Effect of Price on Subjective Product Evaluation, In Jacob and Jerry C. Olson (Eds.), Perceived Quality: How Consumers View Stores and Merchandise.

Sangadji, E.M., dan Sopiah. (2013).
Perilaku
Konsumen
Pendekatan Praktis Disertai Himpunan Jurnal Penelitian. Yogyakarta : Penerbit Andi.

Swastha, Basu. (2009). Manajemen Penjualan. Yogyakarta: BPFE

Tjiptono, Fandy. (2012). Service Management Mewujudkan Layanan Prima. Yogyakarta: CV Andi Offset

Tjiptono, Fandy. (1997). Strategi

Pemasaran. Edisi kedua. Andi: Yogyakarta.

Wang, Ya-Hui \& Li-Yan Chen. (2016).

An Empirical Study of The Effect of Perceived Price on Purchase Intention Evidence from Low-Cost Carriers. International Journal of Business and Social Science Vol.7 No.4. Department of Business Administration. National Chin-Yi University of Technology: Taiwan.

Xia, L., Monroe, K.B. and Cox, J.L. (2004). The price is unfair! a conceptual framework of price unfairness perceptions. Journal 